九州大学学術情報リポジトリ

Kyushu University Institutional Repository

RECORDS OF THE STREPSIPTERA OF SRI LANKA IN THE COLLECTION OF THE SMITHSONIAN INSTITUTION, WITH DESCRIPTIONS OF SEVEN NEW SPECIES (Notulae Strepsipterologicae-VI)

Kifune, Teiji

Hirashima, Yoshihiro

https://doi.org/10.5109/2406

出版情報: ESAKIA. 15，pp. 143-159，1980-10-31. Entomological Laboratory，Faculty of Agriculture, Kyushu University

バージョン：

権利関係 : 


\title{
RECORDS OF THE STREPSIPTERA OF SRI LANKA IN THE COLLECTION OF THE SMITHSONIAN INSTITUTION, WITH DESCRIPTIONS OF SEVEN NEW SPECIES \\ (Notulae Strepsipterologicae-VI) *
}

\author{
TeIJI Kifune \\ Department of Parasitology, School of Medicine \\ Fukuoka University, Fukuoka 814, Japan \\ and \\ YoshIHIRO HIRASHIMA \\ Entomologica 1 Laboratory, Faculty of Agriculture \\ Kyushu University, Fukuoka 812, Japan
}

\begin{abstract}
Based on the material kept at the Smithsonian Institution, Washington, D. C., seven new species of Strepsiptera, Mengenilla orientalis, Stichotrema ceylonense, S. ambiguum, S. krombeini, S. simile, S. minor and Tridactylophagus ceylonensis, are described from Sri Lanka. A species of Paraxenos is also recorded. All of these genera, i. e., Mengenilla, Stichotrema, Paraxenos and Tridactylophagus, are recorded from Sri Lanka for the first time.
\end{abstract}

By the courtesy of Dr. Karl V. Krombein of the Smithsonian Institution, Washington, D. C., we were able to examine several interesting male specimens of Strepsiptera from Sri Lanka. These belong to one of insect collections made by him and his collaborators under the auspices of the Biosystem. atic Studies of the Insects of Ceylon project of the Smithsonian Institution, Washington, D. C. His material of Strepsiptera is not rich in number of specimens, as they are not common insects in any part of the world, but includes as many as 8 species, 7 of which are new to science. Descriptions of these new species are given in this paper. All of the genera here recorded from Sri Lanka are new to the fauna of this country. Thus, an unexpectedly rich fauna of Strepsiptera is detected from Sri Lanka. A list of them from this country is presented on the next page.

* Contribution from the Entomological Laboratory, Faculty of Agriculture, Kyushu University, Fukuoka (Ser. 3, No. 81). 


\section{List of Strepsiptera of Sri Lanka}

Mengenillidae

1. Mengenilla orientalis, new species ( $\left.\sigma^{\top}\right)$

Myrmecolacidae

2. Myrmecolax nietneri Westwood, 1858 ( ১) (Westwood, 1861)

3. Stichotrema ceylonense, new species ( 3 )

4. S. ambiguum, new species ( $\begin{gathered}0 \\ \text { ) }\end{gathered}$

5. S. krombeini, new species ( $\left.\partial^{\pi}\right)$

6. S. simile, new species ( $\left.0^{\top}\right)$

7. S. minor, new species $\left(0^{\top}\right)$

Stylopidae

8. Paraxenos sp. (ふో-puparium on Tachytes)

Halictophagidae

Tridactylophaginae

9. Tridactylophagus ceylonensis, new species ( $\lesssim$ )

Halictophaginae

10. Halictophagus peradeniya (Pierce, 1911) ( $\left.0^{\star}, q\right)$

11. H. sodeni Hofeneder, 1949 ( $\lesssim$, 우)

12. H. spectrus Yang, 1964 ( $\precsim$, 우) (Kinzelbach, 1971)

\section{MENGEN ILLIDAE}

\section{Mengenilla orientalis, new species}

Male (Fig. 1)

Size. Total length of body $2.6 \mathrm{~mm}$; length of head and thorax together $2.1 \mathrm{~mm}$; head breadth $0.72 \mathrm{~mm}$; metathoracic breadth $0.68 \mathrm{~mm}$; length of aedeagus $0.25 \mathrm{~mm}$.

Structure. Typical form of the genus. Head more or less trapezoidal, basements of antennae anteriorly protruded; eyes oval, each eye composed of about 50 facets and about 30 of them visible from above; antennae 6 -segmented, 1st and 2nd segments disc-like, each of 3rd to 5th segments with long flabellum; flabella of 4th and 5th segments slightly surpassing flabellum of 3rd and 6th segments; sensorial pit situated underside of the base of 4th segments; posterior margin of head slightly concave.

Anterior margin of prothorax slightly evolved; posterior half of prothorax narrower than anterior half; posterior margin of mesothorax conspicuously concave ; prescutum semicircularly protruded, posteriorly fused with scuti ; scutellum about twice as long as broad, of isosceles triangle in form, posterior margin concave ; postlumbium with anterior margin curved and posterior margin almost transversely straight; postscutellum as long as prescutum and scutellum together, twice as long as broad at base; legs slender, tarsi 5-seg- 


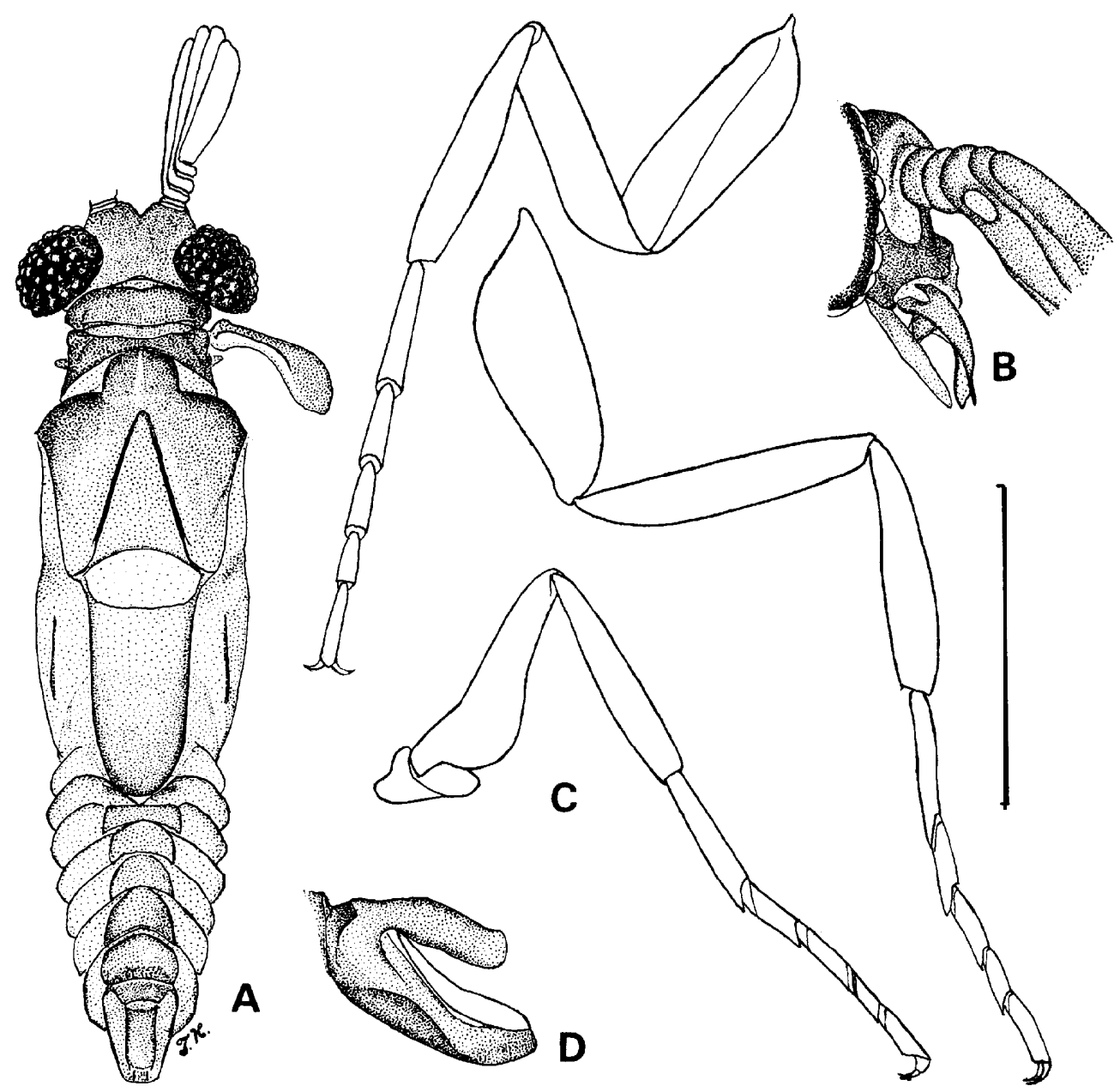

Fig. 1. Mengenilla orientalis, new species. A: Body, dorsal view. B: Right lateroposterior view of head, showing the basal segments of antenna, mandibles, and maxilla. C: Right fore- and left mid- and hind legs, ventral view. D: Left lateral view of terminal segments of abdomen. Scale : $1 \mathrm{~mm}$ for $\mathrm{A}, 0.5 \mathrm{~mm}$ for $\mathrm{B}, \mathrm{C}$, and $\mathrm{D}$.

mented, each with 2 claws.

Abdominal segment tapering toward caudal end; 4th tergite quadrilateral; 5th to 8th tergites semi-elliptical with round anterior and concave posterior margins ; 9th segment long, trapezoidal ; 10th segment (proctiger) long, quadrilateral, about $2 / 3$ as long as aedeagus.

Hind wing with typical venation of the genus.

Female and triungulin. Unknown.

Hos T. Unknown.

Type material : Holotype male, Olatithoduvai, 10 miles NW of Mannar, 
Man. Dist., 0 - 50 ft., at black light, 4 - 5. Nov. 1976, G. F. Hevel, R. E. Dietz IV, S. Karunaratne, \& D. W. Balasooriya leg., preserved in alcohol.

Type Depository: The holotype is preserved in the Department of Entomology, Smithsonian Institution, Washington, D. C., U. S. A.

Remarks: The present new species resembles M.kaszabi Kinzelbach, 1970. from Mongolia, and M.parvula Silvestri, 1941, from Sicily, but differs from the former by the smaller size of body, narrower prescutum, and longer postscutellum, and from the latter by the uniformly tapering aedeagus.

Since Hofeneder (1910) described the first species of this genus, M.chobautii, 16 species and 1 presumable variety have been described from the world. However, 9 of them were already synonymized by Kinzelbach (1970). His treatment seems to be reasonable. He (1979) gave a key to the world species. We propose a different key including the present new species as follows :

\section{Key to THE WORLD SPECIES (MALES) OF Mengenilla}

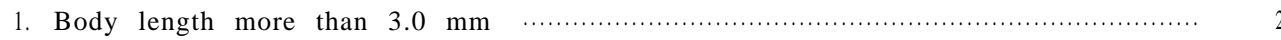

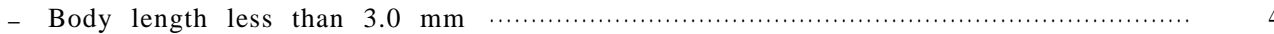

2. Hind wing with fragmental vein of radius (Rf) near radius; length of body $3.2-5.1 \mathrm{~mm}$. Mongolia ….............................. M. kaszabi Kinzelbach, 1970

- Hind wing with fragmental vein of radius (Rf) midway between radius and

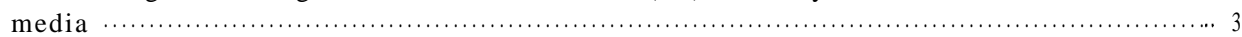

3. Second segment of hind tarsus subequal to 3 rd segment in length; length of body $3.6 \mathrm{~mm}$. Kazakhstan ................................ M. marikovskii Medvedev, 1970

- Second segment of hind tarsus longer than 3rd segment; length of body 3.0$5.9 \mathrm{~mm}$. Algeria, Morocco, Italy (including Sardinia and Sicily), Spain, Portugal …...................................................... M. chobauti Hofeneder, 1910

(= Tetrozocera santchii Pierce, 1918)

(=Mengenillopsis theryi Hofeneder, 1926)

(= M.mauretanica Hofeneder, 1928)

(= Mengenilla quaesita Silvestri, 1933)

(= M. spinulosa Silvestri, 1940)

(= M. nigritula Silvestri, 1941)

(= M. subnigrescens Silvestri, 1941)

(= M. Zaevigata Silvestri, 1941)

(= M. nigritula var. ? quadriarticulata Luna de Carvalho, 1953)

4. Eye composed of $25-27$ facets ; length of body $2.8 \mathrm{~mm}$. Australia

M. gracilipes (Lea, 1910)

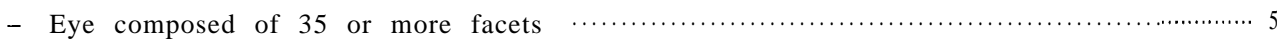

-5. Eye composed of 60 facets; maxillary palp subequal to maxilla in length; length of body 2. $6 \mathrm{~mm}$. China (Shansi) ..................... sinensis Miyamoto, 1960

- Eye composed of 50 or less facets; maxillary palp longer than maxilla …............... 6

6. Eye composed of 50 facets ; basal half of aedeagus slightly thickened; length of body $2.6 \mathrm{~mm}$. Sri Lanka …................................ M. orientalis, new species

- Eye composed of 38 or less facets; basal half of aedeagus remarkably thick-

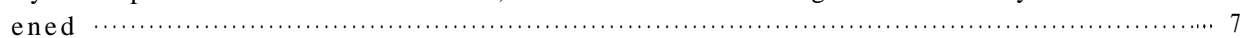


7. Maxilla without lappet; mandible with broad blade and sclerotized apex; length

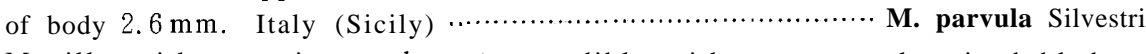
1941

- Maxilla with conspicuous lappet; mandible with narrow, sclerotized blade, widely covered with microtrichia and sensilla; length of body $2.8 \mathrm{~mm}$. Saudi

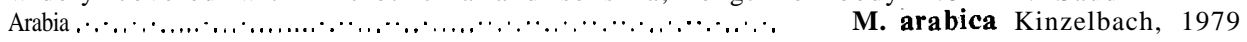

\section{MYRMECOLACIDAE}

\section{Stichotrema ceylonense, new species}

Male (Fig. 2)

Size. Total length of body $1.9-2.0 \mathrm{~mm}$; length of head and thorax together $1.4 \mathrm{~mm}$; head breadth $0.70 \mathrm{~mm}$; metathoracic breadth $0.58 \mathrm{~mm}$; radial length of hind wing $1.7 \mathrm{~mm}$.

Structure. Head dumbbell-formed, basements of antennae triangularly protruded seen from above; eyes hemispherical, each eye composed of about 30 facets and 20 of them visible from above; antenna 7 -segmented, 1st segment cylindrical, as long as broad; 2nd and 4th segments short, each one half as long as broad, equal to each other in size, 3rd segment with long flabellum

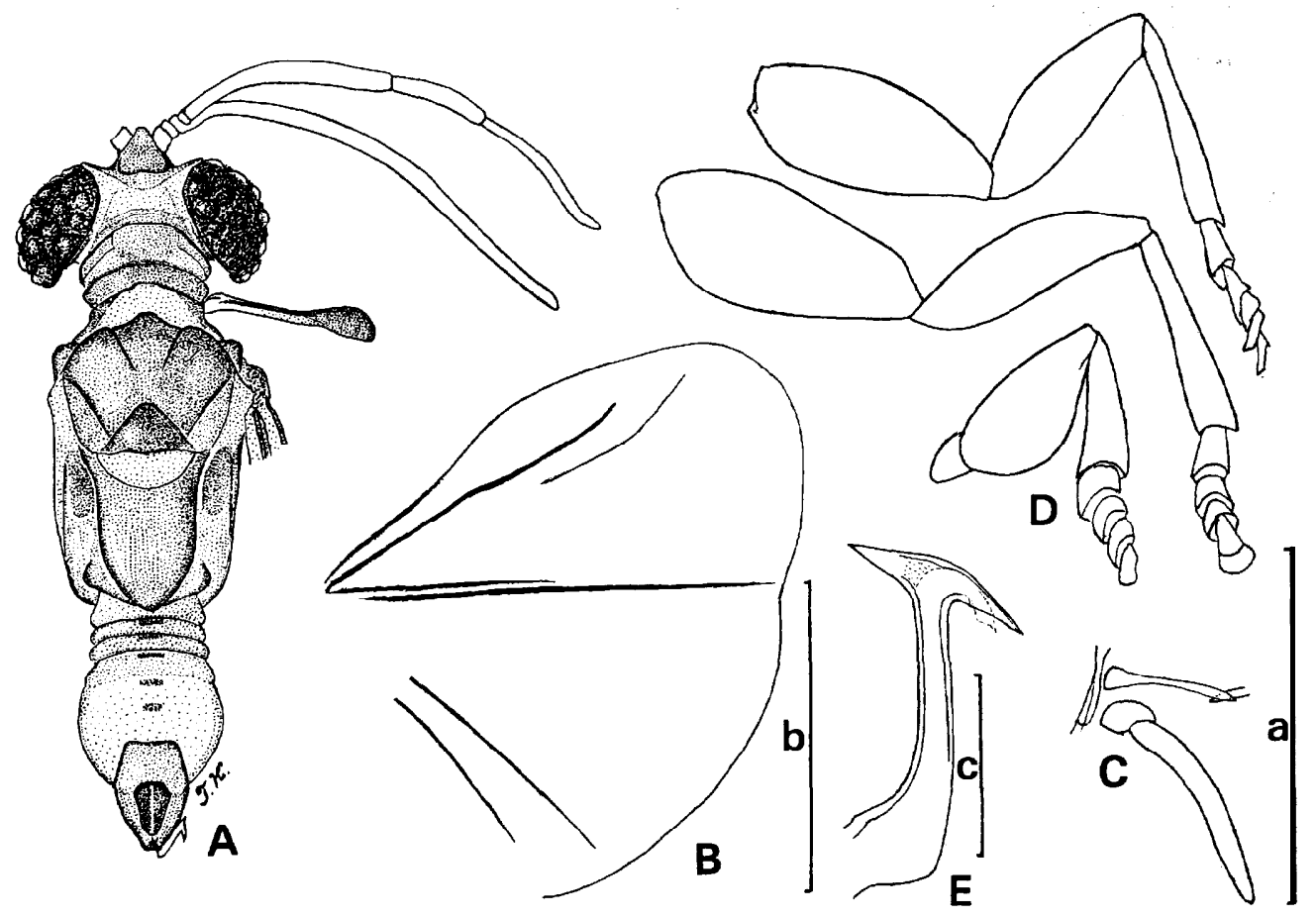

Fig. 2. Stichotrema ceylonense, new species. A: Body, dorsal view. B: Right hind wing. C: Right mandible and maxilla, ventral view. D: Left legs, ventral view. E: Aedeagus, left lateral view. Scale : a: $1 \mathrm{~mm}$ for $A, 0.5 \mathrm{~mm}$ for $\mathrm{C}$ and $\mathrm{D}$. b: $1 \mathrm{~mm}$ for B. c: $0.1 \mathrm{~m} \mathrm{~m}$ for $\mathrm{E}$. 
almost reaching the terminal end of antenna, 5th segment a little shorter than 6th and 7th segments together, 6th segment slightly longer than one half of 7 th.

Prothorax broader than distance between inner margins of eyes, anterior margin roundly curved; mesothorax slightly narrower than prothorax,arcuate; metathorax remarkably narrower than head, prescutum medianly protruded; scuti trapezoidal, posteriorly fused with prescutum ; scutellum triangular ; postlumbium crescent, anterior margin transversely straight; postscutellum twice as long as broad at its midpoint, middle third of lateral margins parallel, posteriorly tapered.

Hind wing with one detached vein near radius; detached vein one half as long as radius; proximal media one half as long as distal media, proximal media terminating near the midpoint of distal media.

Abdomen cylindrical, 4th to 8th tergites slightly sclerotized; 9th abdominal segment pentagonal ; 10th segment tongue-formed.

Female and triungulin. Unknown.

Host. Unknown.

TYPE MATERIALS: Holotype male and 1 paratopotype male, Diyaluma Falls, Koslanda, Bad. Dist ., 3, $000 \mathrm{ft} .$, 10. Mar. 1973, Baumann \& Cross leg., preserved in alcohol.

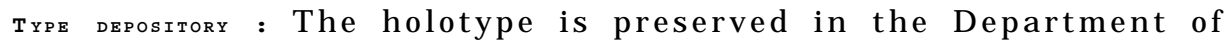
Entomology, Smithsonian Tnstitution, Washington, D.C., U.S.A. The paratopotype is deposited in the collection of the Entomological Laboratory, Faculty of Agriculture, Kyushu University, Japan.

Remarks: This is the largest among the congeneric species discussed in this paper. It is also interesting to note that the flabellum of this species is very long, reaching the end of antenna. So far as we know, this group of species of Stichotrema is restricted to the Oriental Region only.

\section{Stichotrema ambiguum, new species}

M ale (Fig. 3)

Size. Total length of body $1.7 \mathrm{~mm}$; length of head and thorax together $1.2 \mathrm{~mm}$; head breadth $0.63 \mathrm{~mm}$; metathoracic breadth $0.54 \mathrm{~mm}$.

Structure. Head arcuate, posterior margin deeply concave anteriorly; basements of antennae triangularly protruded seen from above; eyes hemispherical, each eye composed of about 25 facets, 15 of them visible from above; antenna 7-segmented, relative lengths of each segment similar to the preceding species in proportion.

Prothorax slightly broader than mesothorax; metathorax slightly narrower than head; prescutum trapezoidal, as broad as scuti; scuti posteriorly fused with prescutum; scutellum semi-elliptical, as long as broad; postlumbium with 


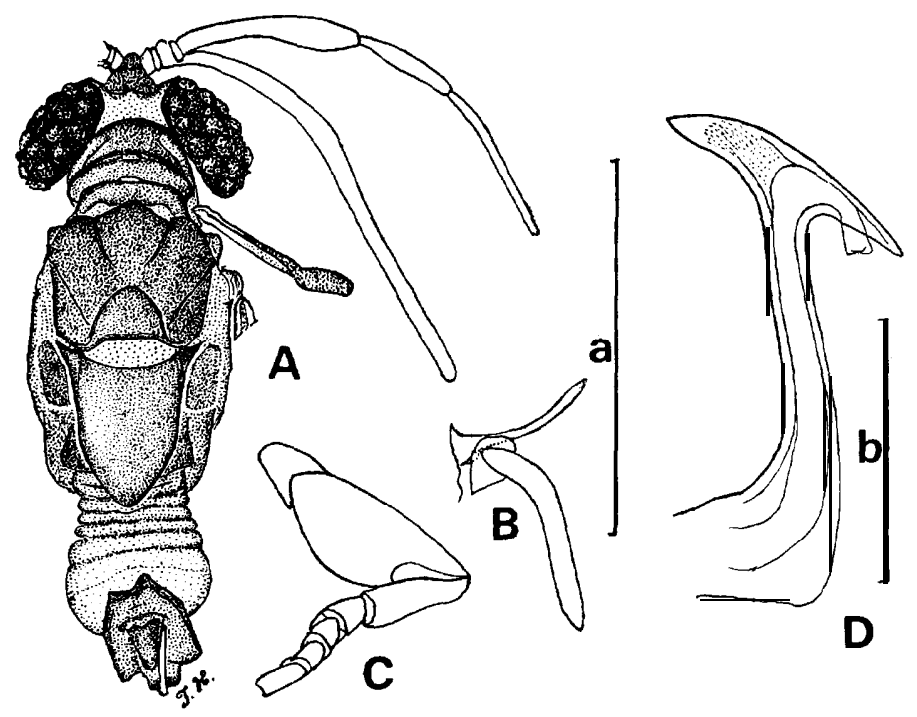

Fig. 3. Stichotrema ambiguum. new species. A: Body, dorsal view. B: Right mandible and maxilla, ventral view. C: Left hind leg, ventral view. D: Aedeagus, left lateral view. Scale: a: $1 \mathrm{~mm}$ for A, $0.5 \mathrm{~mm}$ for $B$ and C. b: $0.1 \mathrm{~mm}$ for D .

arcuate anterior margin ; postscutellum almost pentagonal, slightly less than twice as long as broad.

Hind wing of typical form of the genus.

Female and triungulin. Unknown.

Host. Unknown.

Type material: Holotype male, Diyaluma Falls, Koslanda, Bad. Dist., 3,000 ft., 19. Mar. 1973, Baumann \& Cross leg., preserved in alcohol.

TyPE DEPOSITORY: The holotype is preserved in the Department of Entomology, Smithsonian Institution, Washington, D.C., U.S.A.

REMARKS: This is allied to the preceding new species but differs from it by a slightly smaller size of body and the shape of 9th abdominal segment as shown in Figs. 1 and 2.

\section{Stichotrema krombeini, new species}

Male (Fig. 4)

Size. Total length of body $1.5 \mathrm{~mm}$; length of head and thorax together $1.1 \mathrm{~mm}$; head breadth $0.6 \mathrm{~mm}$; metathoracic breadth $0.46 \mathrm{~mm}$; radial length of hind wing $1.4 \mathrm{~mm}$.

Structure. Head dumbbell-formed ; basements of antennae broadly protruded; eye hemispherical, each eye composed of 25 facets, about 16 of them visible from above; antenna 7-segmented, relative lengths of antenna1 segments similar to the preceding two species, but 7 th segment slightly longer than 
6th; 5th segment subequal to 6 th and 7 th together in length.

Prothorax as broad as mesothorax which is almost equal to distance between inner margins of eyes; metathorax slightly narrower than head ; prescutum trapezoidal, posteriorly fused with scuti ; scutellum triangular ; anterior margin of postscutellum arcuate, posterior margin semicircular; postscutellum conical.

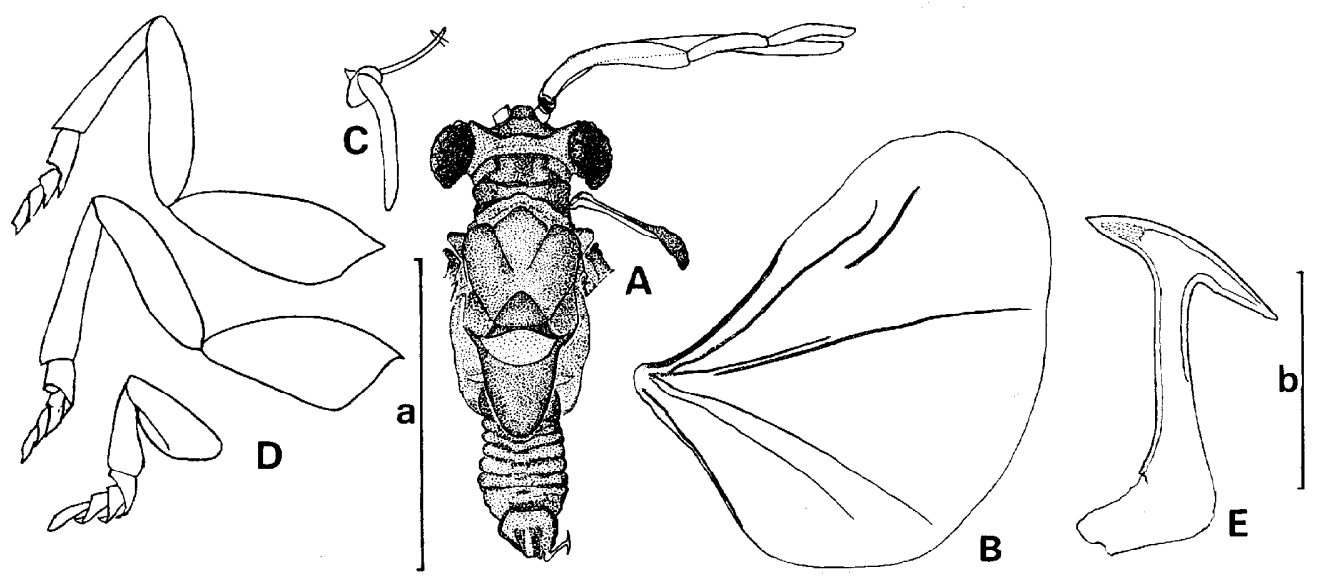

Fig. 4. Stichotrema krombeini, new species. A: Body, dorsal view. B: Right hind wing. C: Right mandible and maxilla, ventral view. D: Right legs, ventral view. E: Aedeagus, left lateral view. Scale: a: $1 \mathrm{~mm}$ for $A$ and $B, 0.5 \mathrm{~mm}$ for $C$ and $D . b: 0.1 \mathrm{~mm}$ for E.

Hind wing with one detached vein near radius; detached vein about onethird as long as radius ; proximal media about two-thirds as long as distal media, terminating near the midpoint of the latter.

Female and triungulin. Unknown.

Host. Unknown.

Type Material : Holotype male, Diyaluma Falls, Koslanda, Bad. Dist., 3,000 ft., 19. Mar. 1973, Baumann \& Cross leg., preserved in alcohol.

Type Depository: The holotype is preserved in the Department of Entomology, Smithsonian Institution, Washington, D.C., U.S.A.

Remarks: The present new species is allied to S. davao (Bohart, 1951), from the Philippines, but differs from it in having the concave anterior margin of head, longer proximal media, and the 6th antenna1 segment which is equal to 7 th segment in length.

This species is named in honor of Dr. Karl V. Krombein of the Smithsonian Institution, whose contribution towards the knowledge of insects of Sri Lanka is distinctive.

\section{Stichotrema simile, new species}

Male (Fig. 5)

Size. Total length of body $1.3 \mathrm{~mm}$; length of head and thorax together $0.86 \mathrm{~mm}$; head breadth $0.46 \mathrm{~mm}$; metathoracic breadth $0.39 \mathrm{~mm}$; radial length of hind wing $1.4 \mathrm{~mm}$. 
Structure. Head arcuate, basements of antennae broadly protruded, prothorax deeply overlapped to the posterior portion of head; distance between inner margins of eyes very short; pro- and mesothoraces much broader than distance between eyes ; scutellum triangular ; postlumbium crescent ; postscutellum rather long, lateral margins straight, tapering to apex, about one half as long as metathorax; general structure allied to the preceding species.
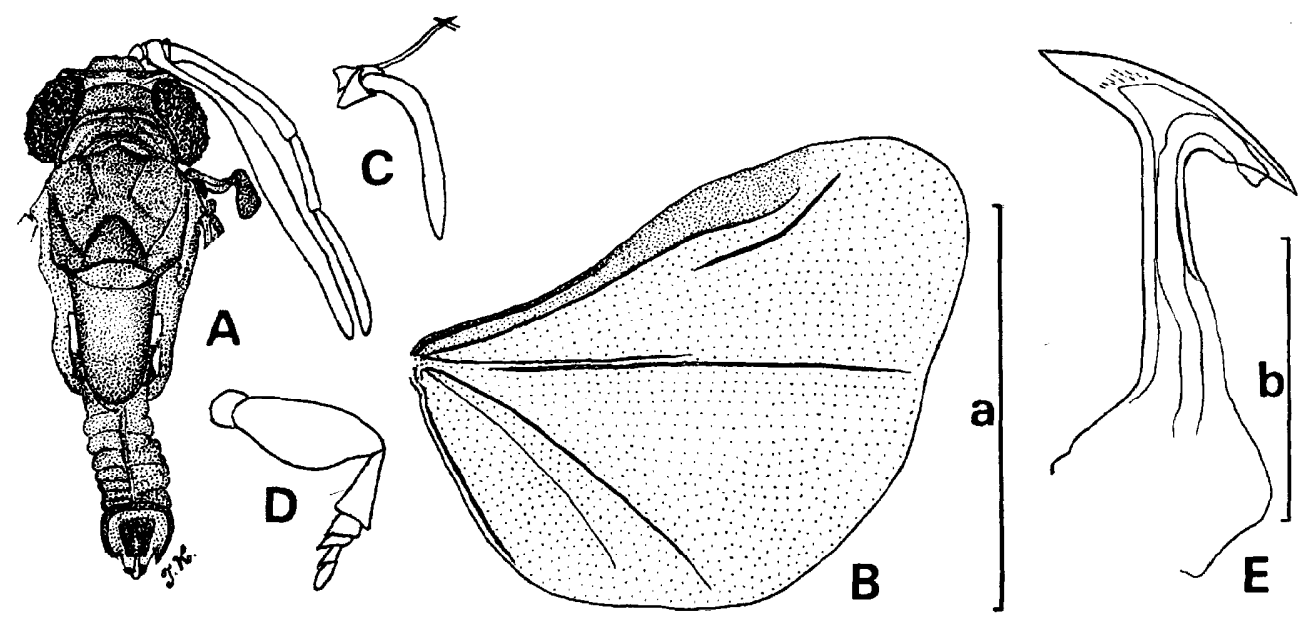

Fig. 5. Stichotrema simile, new species. A : Body, dorsal view. B : Right hind wing, C: Right mandible and maxilla, ventral view. D: Left hind leg, ventral view. E : Aedeagus, left lateral view. Scale : a: $1 \mathrm{~mm}$ for $\mathrm{A}$ and $\mathrm{B}, 0.5 \mathrm{~mm}$ for $\mathrm{C}$ and D. b: 0.1 $\mathrm{mm}$ for $\mathrm{E}$.

Abdomen cylindrical ; median longitudinal groove considerable ; 9th segment rather circular; 10th segment trapezoidal.

Hind wing typical; detached vein rather long, about two-fifths as long as radius; proximal media slightly less than two-thirds of distal media in length, terminating near the midpoint of the latter.

Female and triungulin. Unknown.

Host. Unknown.

Type materials: Holotype male and 3 paratopotype males, Diyaluma Falls, Koslanda, Bad. Dist., 3,000 ft., 19. Mar. 1973, Baumann \& Cross leg., preserved in alcohol.

TYPE DEPOSITORY: The holotype and 2 paratopotypes are preserved in the Department of Entomology, Smithsonian Institution, Washington, D. C., U.S.A. The rest paratopotype is in the collection of the Entomological Laboratory, Faculty of Agriculture, Kyushu University.

REMARKS: This is allied to the preceding new species but separable from it by the shorter distance between eyes, more remarkably curved maxillary palp, and slenderer postscutellum, etc. 


\section{Stichotrema minor, new species}

Male (Fig. 6)

Size. Length of head and thorax together $0.8 \mathrm{~mm}$; head breadth $0.47 \mathrm{~mm}$; metathoracic breadth $0.39 \mathrm{~mm}$; radial length of hind wing $1.1 \mathrm{~mm}$.

Structure. Head transversely elongated; eyes hemispherical, composed of about 15 facets each; antenna 7-segmented, 7th segment slightly longer than 6 th; flabellum of 3 rd segment reaching the base of 7 th segment.

Thorax stout, broad; pro- and mesothoraces narrower than distance between inner margins of eyes; prescutum trapezoidal, scuti fused together behind prescutum ; scutellum as long as broad, subtriangular; postlumbium long, slightly larger than scutellum; postscutellum broad at base, uniformly tapering to apex.

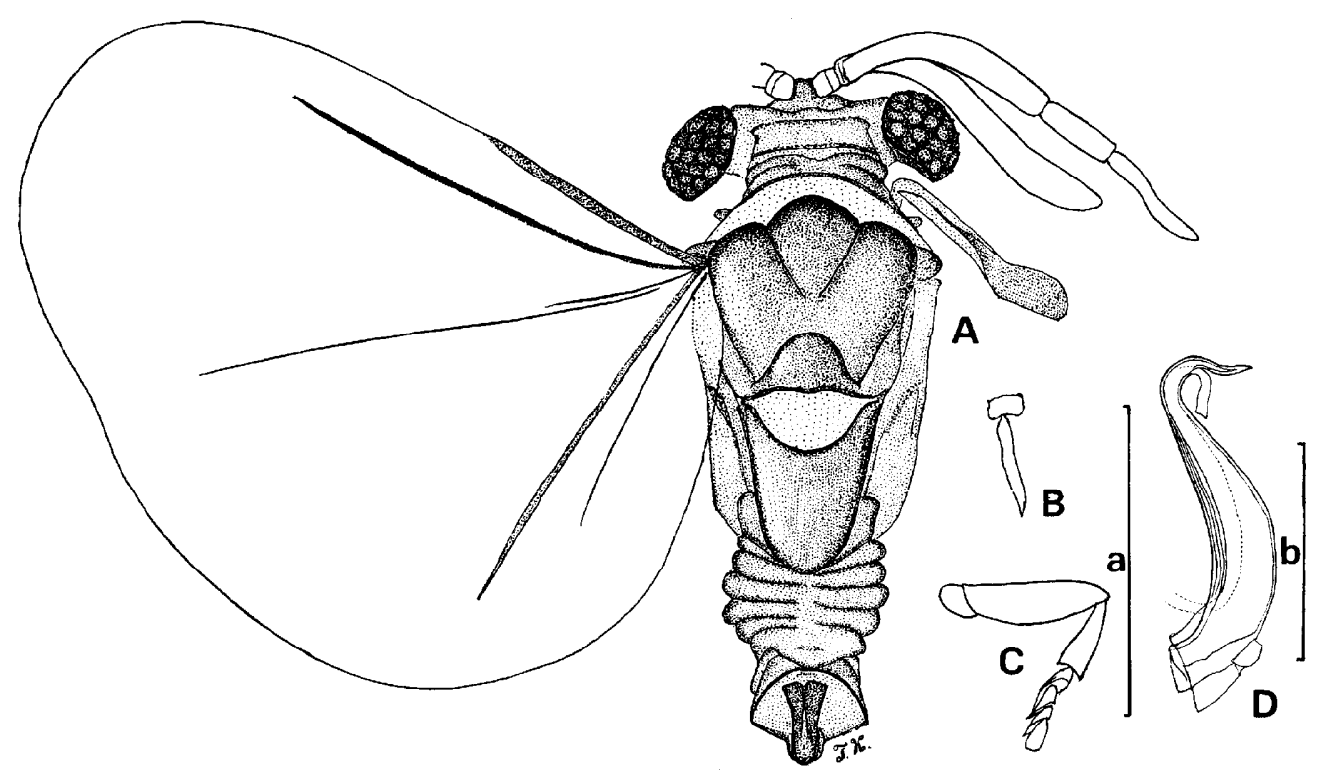

Fig. 6. Stichotrema minor, new species. A : Body, dorsal view. B : Right maxilla, ventral view. C: Left hind leg, ventral view. D: Aedeagus, left lateral view. Scale: a: $0.5 \mathrm{~mm}$ for $\mathrm{A}, \mathrm{B}$, and C. $\mathrm{b}: 0.1 \mathrm{~mm}$ for $\mathrm{D}$.

Abdomen shrinked; 9th abdominal segment semicircular, 10th segment long, basally broadened. Aedeagus without dorsal process, ventral projection curved.

Hind wing without detached vein between radius and media; proximal media about one-third as long as distal media.

Female and triungulin. Unknown.

Host. Unknown.

Type material : Holotype male, Diyaluma Falls, Koslanda, Bad. Dist., 
3,000 ft., 19. Mar. 1973, Baumann \& Cross leg.

TYPE DEPOSITORY: The holotype is preserved in the Department of Entomology, Smithsonian Institution, Washington, D.C.. U.S.A.

REMARKS: This new species is distinguishable from other congeneric species described in this paper by the absence of detached vein between radius and media. This is the main character of the genus Rhipidocolax Bohart. 1951, which is now submerged to Stichotrema. This is allied to S. pasteelsi (Luna de Carvalho, 1956) from Angola and S. ferenczi Luna de Carvalho, 1973, from Ghana, by the shape of aedeagus which does not bear the dorsal process, but differs from them by the longer interocular distance.

In 1971, Kinzelbach redefined the genus Caenocholax Pierce, 1909. The type species of the genus, fenyesi Pierce, 1909, bears a pair of lateral spines on the aedeagus besides the ventral projection. The same is true of C. brasiliensis Oliveira et Kogan, 1959. Therefore, he left these two species in the genus Caenocholax and then transferred almost all species of Caenocholax to Stichotrema Hofeneder, 1910, which had been known by the female only (S. dallatorreanum - the type species).

Conferring with the definition of the related genera by Bohart (1951), we propose the following key to distinguish the myrmecolacid genera. A key to the world species (maies) of Stichotrema is also presented below.

$$
\text { Key to the genera of Myrmecolacidae By males }
$$

1. Hind wing with two vannal veins

Lychnocolax Bohart, 1951

- Hind wing with one vannal vein

2. Hind wing with two detached veins between radius and media

Myrmecolax Westwood, 1858

- Hind wing with one detached vein, or absent between radius and media ............... 3

3. Aedeagus with a pair of lateral spines besides ventral projection

Caenocholax Pierce, 1909

- Aedeagus without such lateral spines Stichotrema Hofeneder, 1910

\section{Key to the WORld species (males) of Stichotrema}

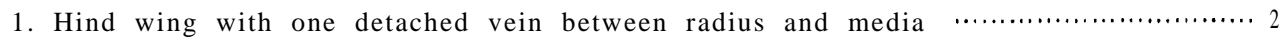

- Hind wing without detached vein between radius and media …......................... 12

2. Detached vein very short and faint; length of body $1.7 \mathrm{~mm}$. Angola, Ghana

Detached vein remarkable

S. rhipidocolaxoides (Luna de Carvalho, 1959)

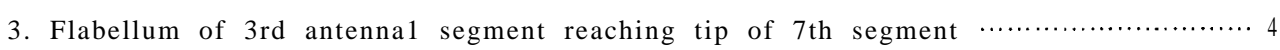

Flabellum of 3 rd antennal segment not reaching base of 7 th segment $\cdots \ldots \ldots \ldots . . . \cdots \times 8$

4. Distance between inner margins of eyes as broad as or slightly broader than

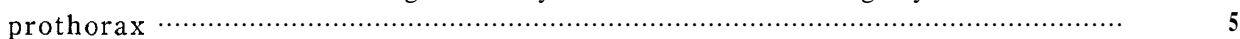

- Distance between inner margins of eyes narrower than prothorax ….................... 6

5. Anterior margin of head almost straight in dorsal view; distal end of proxi- 
mal media (M,) not reaching the midpoint of distal media (M,). Philippines

S. davao (Bohart, 1951)

- Anterior margin of head concave in dorsal view; distal end of proximal media situated near the midpoint of distal media; length of body $1.5 \mathrm{~mm}$. Sri

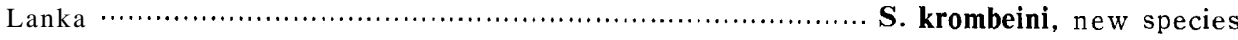

6. Frontal portion between antennal basements protruded anteriorly, trapezoidal in dorsal view; tip of antenna reaching the posterior tip of postscutellum; length of body $1.3 \mathrm{~mm}$. Sri Lanka ............................... S. simile, new species

- Frontal portion between antennal basements protruded anteriorly, triangular in dorsal view; tip of antenna not reaching the posterior tip of postscutellum ........ 7

7. Posterior half of 9 th abdominal segment tapering; maxillary palp slightly arcuate ; length of body 1. $9-2.0 \mathrm{~mm}$. Sri Lanka ............... S. ceylonense, new species

- Posterior half of 9th abdominal segment not tapering, parallel-sided, posterior margin truncated; maxillary palp clearly curved at basal $2 / 5$ of its length; length of body $1.7 \mathrm{~mm}$. Sri Lanka …................... S. ambiguum, new species

8. Prescutum broader than scutellum, its anterior margin triangularly protruded ........ 9

- Prescutum as broad as scutellum, its anterior margin semicirculary protruded $\cdots \cdots \cdots \cdot \ldots$

9. Postlumbium slightly shorter than scutellum; proximal media of hind wing shorter than distal media; length of body $1.7-2.1 \mathrm{~mm}$. Trinidad

\section{S. trinidadense (Günther, 1949)}

- Postlumbium about $1 / 3$ as long as scutellum ; proximal media of hind wing almost as long as distal media; length of body $2.1 \mathrm{~mm}$. Mexico

S. trilobulatum Brailovsky, 1974

10. Dorsal process of aedeagus as long as ventral projection ; maxillary palp almost straight; length of body $2.5 \mathrm{~mm}$. Angola

S. vilhenai (Luna de Carvalho, 1956)

- Dorsal process of aedeagus slightly shorter than ventral projection; maxillary palp slightly curved

11. Postlumbium fusiform, its anterior margin convex. Brazil

S. beckeri (Oliveira et Kogan, 1959)

- Postlumbium crescent, its anterior margin rather transversely straight; length of body $2.2 \mathrm{~mm}$. Brazil ....................... S. wygodzinskyi (Oliveira et Kogan, 1959)

12. Sixth antennal segment cuneiform; base of 7 th segment looking like being connected with tip of 5 th segment: length of body $1.25 \mathrm{~mm}$. Angola

S. anomalum (Luna de Carvalho, 1959)

- Sixth antennal segment normal, 7th segment connected with 6th segment $\cdots \cdots \ldots \ldots \ldots . . .13$

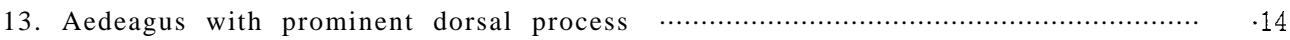

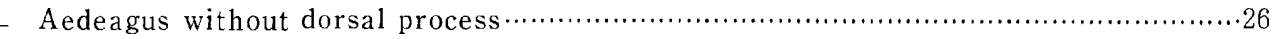

14. Dorsal process of aedeagus more than twice as long as its ventral projection $\cdots \cdots \cdots \cdot 15$

- Dorsal process of aedeagus less than twice as long as its ventral projection $\cdots \cdots \cdots \cdot \cdots \cdot 16$

15. Maxillary palp fusiform, 1. 5 times as long as maxilla. Philippines

S. retrorsum (Bohart, 1951)

- Maxillary palp rod-form, about 8 times as long as broad; length of body 0.96 mm. New Guinea ..................................... S. acutipenis (Kogan et Oliveira, 1964)

16. Length of body $3.5 \mathrm{~mm}$. Angola ................... S. nasutum (Luna de Carvalho, 1967)

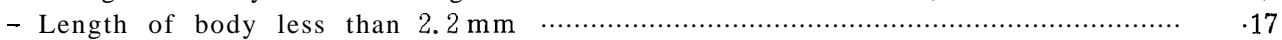

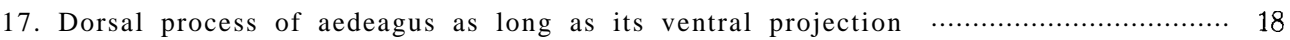

- Dorsal process of aedeagus clearly shorter than its ventral projection ...................19

18. Tenth abdominal segment broadest at about apical third of its length; distance between inner margins of eyes broader than mesothorax; length of body 2.15 mm. Angola

S. lindbergi (Luna de Carvalho, 1959) 
Tenth abdominal segment broadest at base; distance between inner margins of eyes slightly narrower than mesothorax; length of body $1.1 \mathrm{~mm}$. Liberia...

S. harleyi (Fox, 1967)

Seventh antennal segment as long as 6 th segment; length of body $1.6 \mathrm{~mm}$.

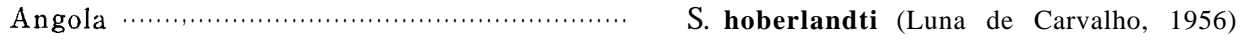

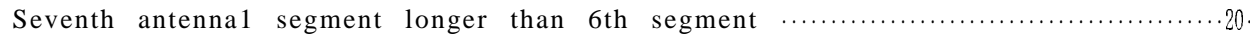

Length of body $2.2 \mathrm{~mm}$. Angola …................. S. golias (Luna de Carvalho, 1956)

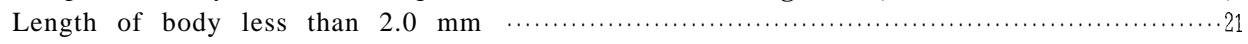

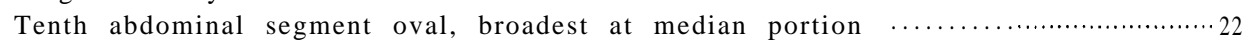

Tenth abdominal segment at least broadest at base, triangular or parallel-

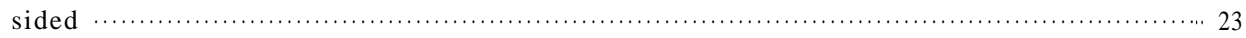

Axis of aedeagus almost straight; flabellum of 3 rd antennal segment not reaching the apex of 6 th segment; length of body $1.2 \mathrm{~mm}$. Ghana

S. rectipennis Luna de Carvalho, 1973

Axis of aedeagus curved; flabellum of 3rd antennal segment reaching the apex of 6 th segment; length of body $1.3 \mathrm{~mm}$. Nigeria, Ghana

S. foxe Luna de Carvalho. 1972

Fifth antennal segment as long as 6th and 7th segments together; length of

body $1.75 \mathrm{~mm}$. Angola, Ghana........................ S. boharti (Luna de Carvalho, 1956)

Fifth antennal segment longer than 6 th and 7 th segments together .................24 Antenna short; flabellum of 3 rd antennal segment not reaching the anterior margin of scuti; length of body $1.0-1.5 \mathrm{~mm}$. Ghana

S. kaszabi Luna de Carvalho, 1973

Antenna not so short, flabellum of 3rd antennal segment reaching the ante-

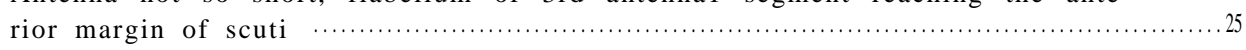

Distance between inner margins of eyes broader than prothorax; basal breadth of postscutellum larger than breadth of postlumbium; length of body $1.4-1.9$

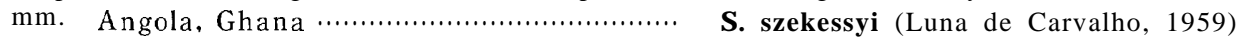
Distance between inner margins of both eyes as broad as prothorax; basal breadth of postscutellum as large as breadth of postlumbium; length of body $1.0 \mathrm{~mm}$. Liberia, Nigeria............................................ S. bassa (Fox, 1967) Distance between inner margins of eyes broader than prothorax; media of hind wing terminating far from wing margin. Sri Lanka ….... S. minor, new species Distance between inner margins of both eyes narrower than prothorax; media

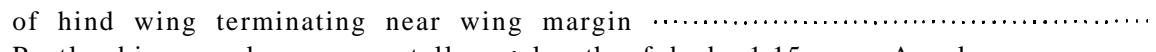

Postlumbium as long as scutellum ; length of body $1.15 \mathrm{~mm}$. Angola

S. pasteelsi (Luna de Carvalho, 1956)

Postlumbium very short, slit-like; length of body 1. $45 \mathrm{~mm}$. Ghana

... ferenczi Luna de Carvalho, 1973

\section{STYLOPIDAE}

\section{Xeninae}

\section{Paraxenos sp.}

One male puparium (unemerged) of Paraxenos sp. is seen on the left side of abdomen between the 4 th and 5th tergites of a female of Tachytes modestus Smith (?) (determined by Dr. Krombein). Because of the limited condition of the material, no further study was made on this specimen. This is the first record of Paraxenos from Sri Lanka. The wasp was taken by the Malaise 
trap, as follows : Induruwa Jungle, Gilimale, Rat. Dist., 7-8. Mar. 1979, K. V. Krombein, P. B. Karunaratne, T. Wijesinhe, S. Siriwardane, \& L. Jayawickrema leg.

REMARKS: Probably this is a relative of Paraxenosindicus (Pierce, 1911) (on Tachytes xenoferus) from Deesa, India, which is the sole parasite of the genus Tachvtes.

\section{HALICTOPHAGIDAE}

\section{TRIDACTYLOPHAGINAE}

\section{Tridactylophagus ceylonensis, new species}

Only one male was found from the present material. Hind wings were separated from the body and mounted in one slide together. The rest of body is preserved in alcohol. Dorsal portion of the head seems to be somewhat depressed probably because of dessication. Abdomen is attached rectangularly to the thorax in this specimen. The measurement of total body length, therefore, is not made.

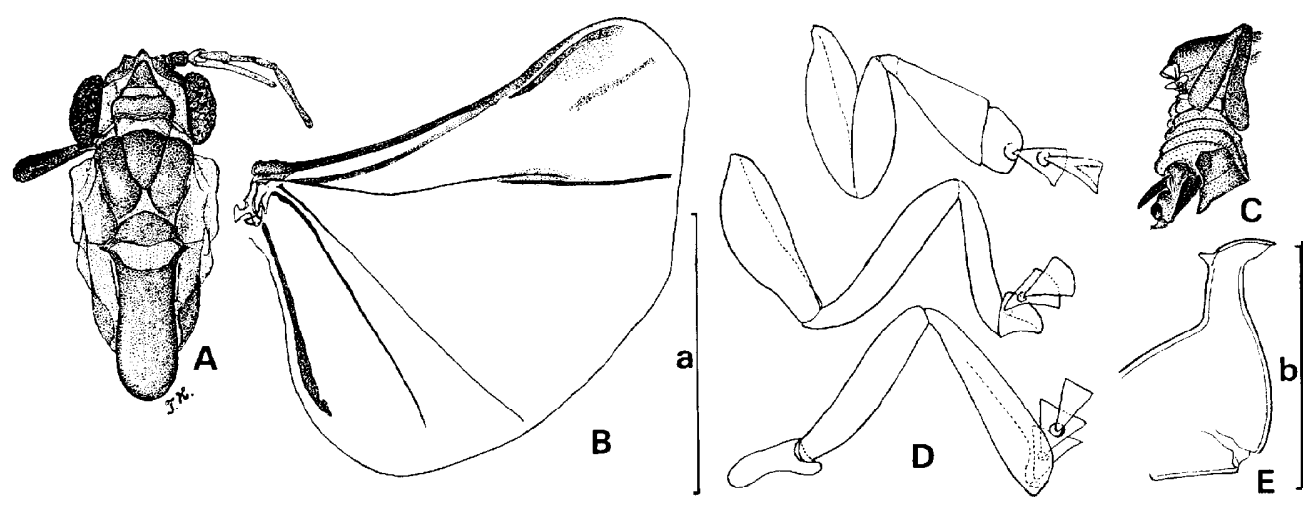

Fig. 7. Tridactylophagus ceylonensis, new species. A: Body, dorsal view. B: Right hind wing. C: Right lateral view of abdomen. D: Left legs, ventral view. E: Aedeagus, left lateral view. Scale: a: $1 \mathrm{~mm}$ for A, B, and C, $0.5 \mathrm{~mm}$ for D. b: $0.1 \mathrm{~mm}$ for E.

Male (Fig. 7)

Size. Length of head and thorax together $1.3 \mathrm{~mm}$; length of abdomen 0.6 $\mathrm{mm}$; head breadth $0.53 \mathrm{~mm}$; metathoracic breadth $0.53 \mathrm{~mm}$.

Structure. Head arcuate, interantennal frontal portion anteriorly protruded, triangular seen from above; antenna1 socket more or less obliquely protruded ; antenna 7-segmented, 1st segment cylindrical, 2nd segment conical, 3rd segment with flabellum, 4th to 7th segments flattened, 6th shortest, 7th subequal to the preceding three segments together in length; eyes spherical, somewhat flattened, each with about 17 facets. 
Pro- and mesothoraces strongly inserted into the dorso-posterior portion of head; prothorax triangular seen from above ; mesothorax belt-like, very short, slightly broader than prescutum ; prescutum triangular, scuti trapezoidal, scutellum semicircular, postlumbium also semicircular, postscutellum long, cylindrical, broadest at about $1 / 4$ of its length from posterior tip.

Hind wing of typical form of the genus but with 2 detached veins between radius and media; detached vein to radius closely situated to the anterolateral angle of the wing; detached vein to media slightly shorter than and closely situated to detached vein to radius; proximal media about two-thirds as long as radial length of wing, distal media about two-thirds as long as proximal media.

Tarsi 3-segmented; foreleg stout, 1st tarsal segment almost quadrilateral, 2nd and 3rd segments triangular; mid- and hindlegs with wholly triangular tarsal segments. Abdomen lo-segmented, bent ventrad; 10th abdominal segment elongated, trapezoidal. Aedeagus with curved ventral projection ; dorsal process of aedeagus not conspicuous.

Female and triungulin. Unknown.

Host. Unknown.

Type material: Holotype male, Hunuwilagama, near Wilpattu, Anu. Dist., $200 \mathrm{ft}$., at black light, 28. Oct. - 3. Nov. 1976, G. F. Hevel, R. E. Dietz IV, S. Karunaratne, \& D. W. Balasooriya leg., preserved in alcohol.

Type depository: The holotype is deposited in the Department of Entomology, Smithsonian Institution, Washington, D.C., U.S.A.

REMARKS: The present new species is allied to T.coniferus (Yang, 1964) from China, but differs from it by the remotely detached vein from the media and the long 7 th antennal segment, etc. This is the first record of the genus from Sri Lanka.

Including the present new species, keys to the world species of the genus Tridactylophagus are given below. Hosts are shown in the key to the females.

KEY TO THE WORLD SPECIES OF Tridactylophagus

MALES

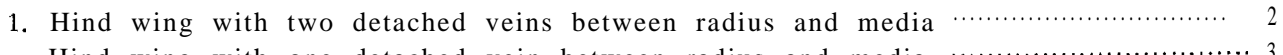

- Hind wing with one detached vein between radius and media ............................. 3

2. Posterior detached vein closely situated to media; 7 th antennal segment subequal to the preceding two segments together in length; length of body 2.5 $\mathrm{mm}$. China ….................................................... coniferus (Yang, 1964)

- Posterior detached vein remote from media; 7th antennal segment subequal to the preceding three segments together in length; length of body less than

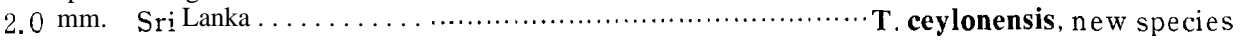


3. One detached vein present between media and cubitus. Philippines

T. similis Kinzelbach, 1971

- No vein present between media and cubitus ......................................... 4

4. Posterior margin of hind wing exceeding the posterior tip of postscutellum; length of body $2.4 \mathrm{~mm}$. China

T. sinensis Yang, 1964

- Posterior margin of hind wing not reaching the posterior tip of postscutellum; length of body $2.04 \mathrm{~mm}$. India ........................ T. mysorensis Subramaniam, 1932

\section{FEMALES}

1. Mandible with two teeth; opening of brood chamber elliptical or crescent $\ldots \ldots \ldots \ldots \ldots . \cdots 2$

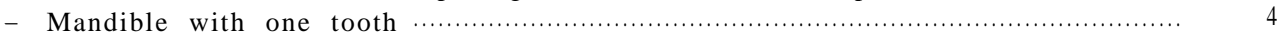

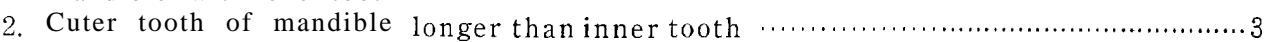

-. Inner tooth of mandible longer and more sharply pointed than outer tooth. Albania. Host: Tridactylus variegatus............................ T. harzi Kinzelbach, 1971

3. Breadth of head at base about twice as broad as the distance between the bases of mandibles. China. Host : Tridactylus japonicus .............. s. sinensis Yang, 1964

- Breadth of head at base less than twice of the-distance between the bases of mandibles. China. Host: Tridactvlus japonicus, T. sp. ............. c. coniferus (Yang, 1964)

4. Opening of brood chamber slit-like; length of cephalothorax 0, $41 \mathrm{~mm}$. India. Host: Tridactylus nigraeneus............................... T. mysorensis Subramaniam. 1932

- Opening of brood chamber belt-like ; length of cephalothorax $0.60 \mathrm{~mm}$. Roumania. Host: Tridactylus tartarus

T. tartari Bechet, 1972

\section{Acknowledgements}

We are very grateful to Dr. Karl V. Krombein, Department of Entomology, Smithsonian Institution, Washington, D. C.. for the loan of the present material. Thanks are also due to Prof. Marco Alberto Bologna, Istituto di Zoologia dell'Università di Roma, for the gift of some copies of Silvestri's papers.

\section{References}

Bechet, I. 1972. Tridactylophagus tartari, une nouvelle espèce de Strepsipteres (Insecta, Strepsiptera). Stud. Univ. Babes-Bolyai, ser. Biol. 17: 99-101.

Bohart, R. M. 1941. A revision of the Strepsiptera with special reference to the species of North America. Univ. Calif.Publ.Ent. 7: 91-159.

- 1951. The Myrmecolacidae of the Philippines (Strepsiptera). Wasmann J. Biol. 9: 83-103.

Brailovsky, H. 1974. 'Una nueva especie de Stichotrema Hofeneder 1910 (Strepsiptera: Myrmecolacidae) para Mexico. Rev. Soc. mex. Hist. nat. 35: 167-173.

Fox, J. W. 1967. Liberian Strepsiptera in the Smithsonian collection with descriptions of seven new Myrmecolacidae. Proc.U. S. Nat. Mus.124(3625): 1-14.

Green, E. E. 1902. A stylopid attracted by light. Ent. month. Mag.(2) 13: 219.

Giinther, V. 1949. Strepsiptera z Trinidadu B.W.I. Casop. Česk. Spol. Ent. 46: 47-50. (In Czech and English)

Hofenedər, K. 1910. Mengenilla n. g. chobautii n. sp. Eine neue Strepsiptere aus Nordafrika. Ber. naturw.-med. Ver. Innsbr. 32: 33-58, 2 pls.

—_ 1926-28. Zwei neue Strepsipteren aus Morokko. Bul.Soc. Sci. nat. Maroc 6: 56-64; $8: 195-211$. 
Kifune, T., \& Y. Hirashima. 1979. Two new species of Strepsiptera from Thailand (Notulae Strepsipterologicae-V). Esakia (14) : 61-71.

Kinzelbach, R. K. 1970. Die männlichen Imagines der Mengenillidae und Mengenilla kaszabi n. sp. Ergebnisse der zoologischen Forschungen von Dr. Z. Kaszab in der Mongolei. Reichenbachia 12 : 217-247.

- 1971. Morphologische Befunde an Fächerflüglern und ihre phylogenetische Bedeutung (Insecta: Strepsiptera). Zoologica (119): 1-256.

— 1979. Insects of Saudi Arabia. Strepsiptera. Fauna of Saudi Arabia I : 331-333. (In German with English abstract)

Kogan, M., \& S. J. Oliveira. 1964. New Guinean Mengeidae and Myrmecolacidae of the American Museum of Natural History (Strepsiptera). Stud. ent. 7: 459-470.

Lea, A. M. 1910. On a new genus of Stylopidae from Australia. Trans. ent. Soc. Lond. 1910: 514-516, pl. 66.

Luna de Carvalho, E. 1953. Contribuiçãopara o conhecimento dos Estrepsipteros de Portugal (III Nota). Mem. Est. Mus. zool. Univ. Coimbra (215) : 5-13.

- 1956. Primeira contribuiçãopara o estudo dos Estrepsipteros angolenses (Insecta Strepsiptera). Puhl. cult. Co. Diam. Angola (29) : 11-54.

— 1959. Segunda contribuição para o estudo dos Estrepsipteros angolenses (Insecta Strepsiptera). Publ.cult. Co. Diam. Angola (41) : 125-154.

_- 1967. Terceira contribuiçãopara o estudo dos Estrepsipteros angolenses (Insecta Strepsiptera). Publ. cult. Co. Diam. Angola (77) : 13-56.

— 1972. Quarta contribuição para o estudo dos Estrepsipteros angolenses (Insecta Strepsiptera). Publ. cult. Co. Diam. Angola (84) : 109-150.

— 1972. Premiere contribution à l'étude des Strepsipteres de la Nigeria (Insecta, Strepsiptera). Ent. Soc. Nigeria occas. Publ. 9: 1-18. (In French and English)

-_ 1973. Entomological explorations in Ghana by Dr. S. Endrödy-Younga. 17. Strepsiptera. Folia ent. hung. (ser. nov.) 26: (suppl.) : 19-55. (In French with English abstract)

Медведев, Л. Н. 1970. Новое для фауны С С С семейство и новые виды Веерокрылых (Strepsiptera) из юго-восточного Казахстана. Энт. Обозр. 49: 199-202. (In Russian with English summary)

Miyamoto, S. 1960. A new strepsipteron from Shansi, North China, Mengenilla sinensis Miyamoto. Mushi 33 : 37-38, pl. 6.

Oliveira, S. J. de, \& M. Kogan. 1959. A contribution to the knowledge of the Brazilian Strepsiptera (Insecta). Mem. Inst. Oswaldo Cruz 57: 219-233.

Pierce, W. D. 1911. Notes on insects of the order Strepsiptera, with descriptions of new species. Proc.U. S. Nat. M us. 40: 487-511.

Silvestri, F. 1933. Descrizione della femmina e del maschio di una nuova specie di Mengenilla Hofeneder (Strepsiptera). Boll. Lab, Zool. gen. Agr. R. Ist. super. Agr.Portici 28: $1-10$.

— 1940. Descrizione preliminare di una specie nuova di Mengenilla (“M. spinulosa, Insecta, Strepsiptera") della Sicilia e notizie sul suo ciclo e sul particolare modo di fecondazione. Atti R. Accad. Ital. Rend. Cl. jis. mat. nat. (7) 1:614-618.

- 1941. Notizie, specialmente corologiche e biologiche, sulle specie di Mengenilla (Insecta Strepsiptera) finora trovate in Italia. Acta Pont. Acad. sci. 5: 57-65.

Subramaniam, T. V. 1932. On a new genus and species of Strepsiptera. Rec. Ind. Mus. $34: 43-46$, pl. 4.

Yang, C.-k. 1964. Notes on the new subfamily Tridactylophaginae (Strepsiptera :Halictophagidae). Actaent. sin. 13: 606-612. (In Chinese with English text) 